\title{
PENINGKATAN KEMAMPUAN MENULIS CERITA DENGAN MENGGUNAKAN MEDIA FILM ANIMASI PADA SISWA VI SDN 1 SIGLI
}

\author{
${ }^{1}$ Nanda Saputra \\ ${ }^{1}$ STIT Al-Hilal Sigli, Jalan Lingkar Keunire - Pidie, Aceh, Telp. 0653 - 23467 \\ e-mail: nandasaputra680@gmail.com
}

\begin{abstract}
Abstrak
Tujuan penelitian ini adalah untuk meningkatkan: 1) keaktifan dalam menulis cerita, dan 2) kemampuan menulis cerita melalui media film animasi. Penelitian ini merupakan Penelitian Tindakan Kelas (PTK). Penelitian ini dilaksanakan dalam dua siklus, tiap siklus terdiri atas perencanaan, pelaksanaan tindakan, observasi, dan refleksi. Subjek penelitian adalah siswa kelas VI SDN 1 Sigli yang berjumlah 30 siswa. Hasil penelitian menunjukkan bahwa dengan menggunakan media film animasi dapat meningkatkan keaktifan dan kemampuan menulis cerita siswa dari prasiklus ke siklus I dan dari siklus I ke siklus II. Berdasarkan hasil penelitian dapat disimpulkan bahwa: (1) pembelajaran dengan menggunakan media film animasi dapat meningkatkan keaktifan siswa. Keaktifan terlihat dari hasil observasi terhadap proses pembelajaran siswa yaitu, sebelum tindakan sebesar 30\%, siklus I sebesar $65 \%$ dan siklus II sebesar $85 \%$; (2) pembelajaran dengan menggunakan media film animasi dapat meningkatkan kemampuan menulis cerita. Peningkatan kemampuan menulis cerita terlihat dari hasil pekerjaan siswa yaitu, sebelum tindakan sebesar 35\%, siklus I sebesar 70\%, dan pada siklus II sebanyak $90 \%$.
\end{abstract}

Kata Kunci: kemampuan, menulis cerita, media film animasi

\begin{abstract}
The purpose of this study was to improve: 1) activeness in writing stories, and 2) the ability to write stories through animated film media. This research is a Classroom Action Research (PTK). This research was conducted in two cycles, each cycle consisting of planning, acting, observing, and reflecting. The research subjects were students of class VI SDN 1 Sigli, totaling 30 students. The results showed that using animated film media could increase the activeness and ability of students to write stories from pre-cycle to cycle I and from cycle I to cycle II. Based on the research results, it can be concluded that: (1) learning using animated film media can increase student activity. Activeness can be seen from the results of observations of the student learning process, namely, before the action was $30 \%$, cycle I was $65 \%$ and cycle II was $85 \%$; (2) learning using animated film media can improve story writing skills. The increase in the ability to write stories can be seen from the results of student work, namely, before the action was 35\%, cycle I was 70\%, and cycle II was $90 \%$.
\end{abstract}

Keywords: ability, story writing, animated film media 


\section{PENDAHULUAN}

Peran guru dalam pembelajaran bahasa khususnya dalam keterampilan menulis sangat penting. Dalam proses pembelajaran, pengajar mempunyai tugas untuk mendorong, membimbing, dan memberi fasilitas belajar bagi pembelajar untuk mencapai tujuan, pengajar mempunyai tanggung jawab untuk melihat segala sesuatu yang terjadi dalam kelas dalam rangka membantu proses perkembangan pembelajar (Iskandarwassid dan Sunendar, 2008:158). Akan tetapi, pada masa sekarang ini metode pembelajaran menulis yang digunakan oleh kebanyakan guru masih menggunakan metode yang konvensional. Terlihat pada aktivitas pengajaran bahasa khususnya menulis, dengan masih menggunakan metode ceramah yang lebih dominan. Hal ini menimbulkan kejenuhan dan kebosanan pada siswa dalam mengikuti pembelajaran menulis di kelas.

Kemampuan menulis siswa perlu diperhatikan oleh para pendidik. Hal ini diperlukan untuk menunjang keberhasilan dalam proses akademik di sekolahnya. Karena kemampuan menulis siswa harus diperhatikan dan diberi motivasi agar siswa terdorong untuk terampil dalam mengembangkan keterampilannya dalam menulis. Guru sebagai tenaga profesional harus memiliki sejumlah kemampuan seperti mengaplikasikan berbagai teori belajar di bidang pengajaran, kemampuan memilih dan menerapkan metode pengajaran yang efektif dan efisien, kemampuan melibatkan siswa berpartisipasi aktif, dan kemampuan menciptakan suasana belajar yang menunjang agar tercapainya tujuan pendidikan.

Menulis merupakan salah satu keterampilan berbahasa yang sangat penting terutama di Sekolah Dasar. Setiap keterampilan sangat berkaitan dengan keterampilan yang lainnya seperti membaca, menyimak, mendengarkan. Resmini Novi (2012:115) mengungkapkan bahwa menulis merupakan kegiatan yang dapat dilihat sebagai (1) salah satu keterampilan berbahasa, (2) proses berpikir menuangkan ide atau gagasan, (3) kegiatan menyampaikan informasi, (4) sebagai media berkomunikasi. Menurut Sumardjo (2007:75), menulis merupakan suatu proses melahirkan tulisan yang berisi gagasan. Dengan keterampilan menulis, diharapkan dapat melatih siswa untuk mengungkapkan gagasan dan ide kreatifnya ke dalam bentuk tulisan. Menulis merupakan suatu kegiatan yang produktif dan ekspresif (Henry Guntur Tarigan, 2008: 4). Kemampuan menulis tidak dapat diperoleh secara alamiah, tetapi melalui proses belajar mengajar atau latihan yang banyak dan teratur (Sabarti Akhadiah, dkk. 1997:81). Berdasarkan pendapat tersebut bahwa menulis merupakan salah 
satu keterampilan yang harus dicapai dalam pembelajaran bahasa Indonesia di sekolah Dasar khususnya dalam materi menulis cerita pendek.

Berdasarkan hasil wawancara dan observasi yang dilakukan di kelas VI SDN 1 Sigli diperoleh data bahwa proses belajar mengajar guru dan siswa di dalam kelas mengenai pembelajaran menulis cerita pendek peneliti melihat aktivitas pembelajaran dan cara mengajar guru dalam menulis cerita. Media yang digunakan kurang bervariasi dan menarik karena guru hanya menggunakan buku sebagai media. Pada saat kegiatan belajar mengajar, guru meminta siswa untuk membaca buku terlebih dahulu, siswa memperhatikan gambar yang ada dibuku sebelum menulis cerita. Siswa yang malas hanya main-main dan mengganggu temannya, sehingga suasana di dalam kelas menjadi tidak kondusif. Hal itulah salah satu yang menyebabkan kemampuan menulis siswa menjadi rendah, rendahnya kemampuan menulis siswa terlihat jelas dari hasil nilai rata-rata siswa kelas VI SDN 1 Sigli yang masih dibawah KKM.

Dari permasalahan yang telah dipaparkan, peneliti mencoba untuk menggunakan media pembelajaran yang inovatif agar siswa, lebih aktif, kreatif, dan termotivasi. dalam mengembangkan ide dan menuangkannya menjadi sebuah tulisan. Solusi yang akan peneliti gunakan yaitu dengan menggunakan media film animasi. Arsyad (2009:15) memandang bahwa hal yang paling penting dalam suatu pembelajaran adalah media pembelajaran dan metode pembelajaran, seperti yang dikemukakannya bahwa, dalam suatu proses pembelajaran, terdapat dua hal yang amat penting adalah media pembelajaran dan metode pembelajaran. Kedua aspek tersebut saling berkesinambungan.

Menurut Soeparno (2008:1), media merupakan suatu alat yang dipakai sebagai saluran (channel) untuk menyampaikan suatu pesan (message) atau informasi dari suatu sumber (resource) kepada penerimanya (receiver). Dengan adanya media, siswa tidak saja mengaktifkan indra pendengarannya dan mendengarkan penjelasan guru, tetapi juga indra penglihatan, perasa dan sebagainya (Dadan Djuanda, 2016:102).

Pemilihan salah satu metode akan mempengaruhi media pembelajaran, meskipun masih ada berbagai hal lain yang harus diperhatikan dalam memilih media, antara lain tujuan pembelajaran, jenis media, waktu, tanggapan yang diharapkan siswa kuasai setelah pembelajaran berlangsung, dan konteks pembelajaran termasuk karakteristik siswa". 
Berdasarkan definisi tersebut, artinya media pembelajaran berperan penting dalam proses belajar mengajar, media dapat membantu proses pembelajaran saat berlangsung. Media dapat membantu siswa dalam memahami pesan yang disampaikan oleh guru dan membantu guru dalam menyampaikan pelajaran.

Media memegang peranan penting dalam pembelajaran bahasa Indonesia. Dengan media yang sesuai, siswa dapat menangkap penjelasan dari guru dengan mudah. Begitu juga dalam pembelajaran menulis cerpen, yaitu dengan menggunakan film animasi sebagai medianya. Dengan media film animasi diharapkan pembelajaran menulis cerpen lebih efektif dan siswa dapat dengan mudah menuangkan ide-ide atau imajinasinya ke dalam sebuah karya sastra yaitu cerpen dan dapat menghasilkan tulisan cerpen yang baik.

Adapun yang menjadi permasalahan dalam penelitian ini adalah 1) apakah penggunaan media film animasi dapat meningkatkan kemampuan siswa menulis cerita pada kelas VI SDN 1 Sigli?, 2) apakah penggunaan media film animasi dapat meningkatkan keaktifan siswa menulis cerita pada kelas VI SDN 1 Sigli?. Dan yang menjadi tujuan penelitian ini adalah 1) kemampuan dalam menulis cerita, dan 2) keaktifan menulis cerita siswa kelas VI SDN 1 Sigli melalui media film animasi.

\section{METODE PENELITIAN}

Jenis penelitian yang digunakan adalah penelitian tindakan kelas (PTK). Penelitian ini bermaksud meningkatkan kemampuan siswa dalam menulis cerpen melalui penggunaan media film animasi. Untuk mengetahui peningkatan kemampuan siswa dalam menulis cerpen, guru memberikan tes awal yang dilaksanakan sebagai bahan refleksi menentukan tindakan selanjutnya. Subjek penelitian ini adalah guru dan siswa kelas VI SDN 1 Sigli yang berjumlah 30 siswa yang terdiri dari 16 siswa laki-laki dan 14 siswa perempuan. Adapun tahapan penelitian ini menurut Arikunto (2012:131) adalah (1) planning; (2) action; (3) observation and evaluation; (4) reflecting. Dan seterusnya sampai perbaikan atau peningkatan yang diharapkan tercapai (kriteria keberhasilan).

Sumber data dikumpulkan dari berbagai sumber, yang meliputi: (1) Narasumber, yaitu guru bahasa indonesia dan siswa; (2) Tempat dan peristiwa yaitu berbagai kegiatan pembelajaran menulis cerita yang berlangsung di kelas VI SDN 1 Sigli; (3) Dokumen, meliputi foto kegiatan pembelajaran menulis cerita yang terjadi, hasil tes siswa, rencana 
pelaksanaan pembelajaran yang dibuat oleh guru dan peneliti, silabus yang ditentukan oleh pihak sekolah, catatan wawancara.

Teknik pengumpulan data dengan menggunakan pengamatan/ observasi, wawancara mendalam dan pemberian tes. Validitas data dicek dengan triangulasi data dan triangulasi metode. Teknik analisis data yang digunakan dalam penelitian adalah teknik analisis komparatif deskriptif. Menurut Hasan (2002:126-127) analisis komparasi atau perbandingan adalah prosedur statistik guna menguji perbedaan diantara dua kelompok data (variabel) atau lebih. Teknik ini digunakan untuk mengungkapkan berbagai kelebihan dan kelemahan kinerja guru dan siswa dalam proses pembelajaran dan membandingkan pencapaian hasil yang dicapai pada masing-masing siklus. Hasil analisisnya dijadikan dasar dalam penyusunan perencanaan tindakan untuk tahap berikutnya.

\section{HASIL DAN PEMBAHASAN}

Sebelum pelaksanaan penelitian, peneliti melakukan observasi awal terlebih dahulu guna mengetahui kondisi yang terjadi di lapangan, yaitu di SDN 1 Sigli. Observasi dilakukan saat pembelajaran menulis cerita yang dilaksanakan di kelas VI SDN 1 Sigli. Selain itu, dilakukan pula wawancara dengan siswa dan guru. Dari kegiatan ini diketahui kondisi nyata yang terjadi pada pembelajaran menulis cerita di Kelas VI SDN 1 Sigli. Dari observasi awal ini juga diketahui bahwa terdapat masalah dalam pembelajaran menulis cerita.

Berdasarkan hasil observasi awal, peneliti menemukan bahwa keaktifan dan kemampuan menulis cerita siswa kelas VI SDN 1 Sigli bisa dikatakan tergolong kurang apabila dibandingkan dengan nilai keterampilan berbahasa dan bersastra Indonesia lainnya (menyimak, berbicara, dan membaca). Oleh sebab itu, peneliti berkolaborasi dengan guru kelas yang bersangkutan guna memperoleh solusi untuk mengatasi masalah tersebut. Setelah peneliti dan guru mengadakan diskusi, akhirnya disepakatipenggunaan metode picture and pictureuntuk memperbaiki pembelajaran menulis cerita di kelas VI SDN 1 Sigli.

Selanjutnya, peneliti dan guru kelasmenyusun rencana pelaksanaan pembelajaran (RPP) guna melaksanakan tindakan di siklus I. Tindakan I disiklus I merupakan tindakan awal untuk memperbaiki pembelajaran menulis cerita dengan menggunakan media film animasi. Dari tindakan I dideskripsikan hasil pembelajaran menulis cerita dengan menggunakan media film 
animasi. Dari hasil pengamatan terhadap pembelajaran menulis ceritapada siklus I, ternyata masih terdapat kelemahan. Kelemahan yang terjadi pada siklus I tersebut berasal dari guru dan siswa. Dari guru diperoleh hasil bahwa guru kurang mengelola kelas dengan baik karena banyak kegiatan yang seharusnya dilakukan sesuai dengan RPP tetapi belum terlaksana.

Dari siswa diketahui bahwa mereka kurang termotivasi dan aktif dalam mengikuti pembelajaran menulis cerita sehingga antusias dan minat belajar siswa masih rendah. Hal tersebut dapat dilihat dari aktivitas siswa yang belum sepenuhnya aktif pada saat berlangsungnya pembelajaranmenulis cerita. Pada umumnya siswa masih mengabaikan materi. Mereka lebih banyak bercanda dengan teman sebangkunya atau melakukan aktivitas lain. Selain itu, hasil tulisan mereka juga masih banyak yang belum mencapai batas KKM. Hal ini dikarenakan para siswa masih mengalami kesulitan dalam menuliscerita. Kelemahan tersebut dapat dimaklumi karena tindakan yang dilakukan merupakan siklus pertama dalam penelitian ini.

Selanjutnya, siklus II dilaksanakan untuk mengatasi kelemahan atau kekurangan yang terjadi pada siklus I. Setelah peneliti berdiskusi dengan guru, akhirnya diperoleh kesepakatan mengenai solusi yang harus dilakukan guru sebagai bahan perbaikan dari siklus I. Solusi tersebut berupa pengaturan kelas yang lebih baik lagi serta pemberian motivasi kepada siswa. Pendalaman materi pun juga diupayakan untuk meningkatkan pemahaman siswa.

Dari hasil pelaksanaan siklus II, ada peningkatan keaktifan dan kemampuan menulis cerita siswa jika dibandingkan dengan siklus I. Siklus II merupakan siklus terakhir dalam penelitian ini. Pada siklus ini guru dan peneliti berupaya memperkecil segala kelemahan atau kekurangan yang terjadi selama pelaksanaan pembelajaran menulis puisi. Pelaksanaan siklus terakhir dengan menggunakan media film animasi ini merupakan siklus yang menguatkan hasil pada siklus I bahwa penggunaan media film animasi dapat meningkatkan keaktifan dan kemampuan menulis cerita pada siswa kelas VI SDN 1 Sigli.

Pada siklus I, jumlah siswa yang telah mencapai batas minimal ketuntasan hasil belajar sebanyak 18 siswa, sedangkan pada siklus II terjadi peningkatan sebanyak 6 siswa dari sebelumnya. Dari data tersebut, bisa dikatakan hampir semua siswa berhasil mencapai batas minimal ketuntasan hasil belajar menulis cerita. Jumlah siswa yang lulus adalah 24 siswa hanya 6 siswa yang tidak lulus. 
Berdasarkan tindakan-tindakan yang telah disebutkan di atas, guru dikatakan telah berhasil melaksanakan pembelajaran menulis cerita dengan penggunaan media film animasi. Tindakan tersebut mampu membantu siswa dalam menuangkan ide/gagasan dan kosa kata sehingga mampu menulis cerita dengan baik. Selain itu tindakan ini juga dapat meningkatkan minat dan motivasi mereka dalam mengikuti pembelajaran menulis. Terbukti dengan banyaknya siswa yang aktif yaitu berinisiatif, aktif bertanya dan menjawab, dan ketepatan waktu dalam mengerjakan tugas. Dari hasil pelaksanaan tindakan yang dilaksanakan tiap siklus, dapat dikatakan bahwa penelitian ini bermanfaat untuk meningkatkan keterampilan guru dalam mengelola kelas karena media film animasi dapat digunakan sebagai sarana pendukung bagi guru untuk lebih meningkatkan keaktifan siswa selama pembelajaran dan kemampuan siswa dalam menulis cerita.

Keberhasilan media film animasi dalam meningkatkan keaktifan siswa selama pembelajaran dan kemampuan siswa dalam menulis cerita dapat dilihat dari indikatorindikator sebagai berikut.

\section{Keaktifan siswa selama pembelajaran menulis cerita meningkat}

Keaktifan siswa dalam pembelajaran menulis cerita pendek mengalami peningkatan. Hal itu terlihat dari indikator keaktifan siswa dalam pembelajaran yang selalu mengalami peningkatan disetiap siklus. Tindakan berupa penggunaan media film animasi yang dilaksanakan tiap siklus mampu meningkatkan keaktifan siswa kelas VI SDN 1 Sigli selama pembelajaran menulis cerita.

Dari hasil analisis peneliti dapat diketahui bahwa keaktifan siswa pada siklus I mencapai 65\%, meningkat jauh lebih baik dari sebelumnya (survei awal) yang kurang dari $30 \%$. Pada siklus II, keaktifan siswa meningkat menjadi $85 \%$ artinya jumlah siswa yang aktif bertambah 6 siswa. Siswa yang aktif dalam siklus II ini adalah 24 siswa dari 30 siswa.

Dari hasil analisis di atas, maka dapat dikatakan bahwa tindakan yang dilakukan guru untuk meningkatkan keaktifan siswa cukup berhasil. Hal ini membuktikan bahwa media film animasi memiliki peran dalam meningkatkan keaktifan siswa dalam proses belajar mengajar.

Berikut disajikan grafik peningkatan persentase keaktifan pembelajaran menulis cerita dengan media film animasi pada siswa kelas VI SDN 1 Sigli. 


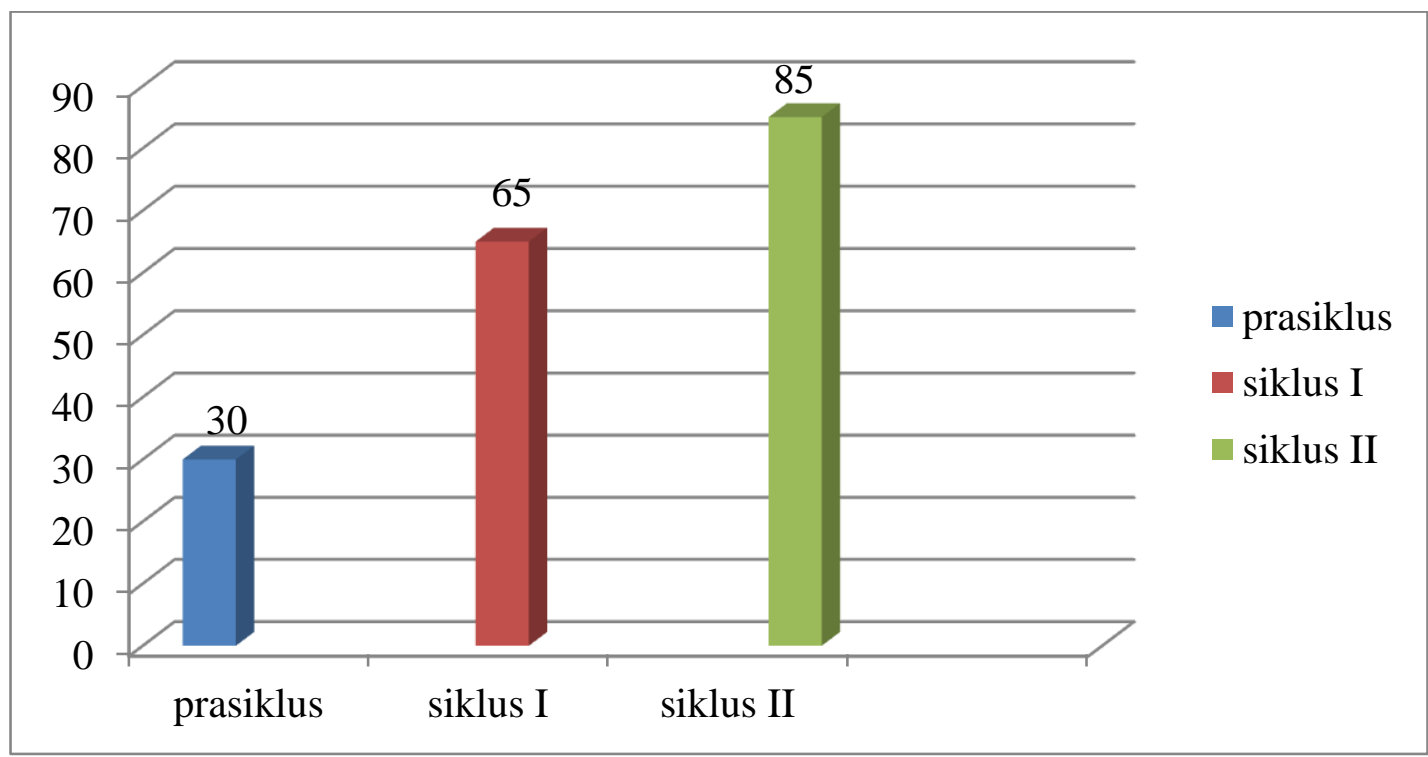

Grafik 1. Rekapitulasi Persentase Peningkatan Keaktifan Siswa dalam Pembelajaran Menulis Cerita Siswa Kelas VI SDN 1 Sigli

\section{Kemampuan Menulis Cerita Pendek Meningkat}

Untuk mengatasi permasalahan tentang kelemahan siswa dalam menulis cerita, guru dan peneliti menyusun tindakan yang terangkum dalam dua siklus. Pada siklus I dan II, digunakan media film animasi. Pelaksanaan siklus I masih belum sepenuhnya mampu mengatasi permasalahan yang terjadi. Berdasarkan hasil analisis dan refleksi yang dilakukan oleh guru dan peneliti, lalu disusunlah instrumen untuk melakukan tindakan pada siklus II. Pada siklus II ini, indikator keberhasilan yang direncanakan sudah dapat dicapai. Kekurangan-kekurangan yang terjadi pada siklus I sudah dapat diatasi.

Kemampuan siswa dalam pembelajaran menulis cerita pendek dapat dilihat dari nilai yang diperoleh siswa dalam menghasilkan sebuah cerita. Nilai tersebut terus mengalami peningkatan dari siklus ke siklus. Cerita yang dihasilkan siswa mengalami peningkatan dalam beberapa aspek baik dari isi, organisasi, kosa kata, penggunaan bahasa dan mekanik.

Peningkatan dari setiap aspek penulisan tersebut menjadikan nilai siswa dalam menulis cerita secara otomatis meningkat. Pada saat observasi awal diketahui bahwa kemampuan siswa dalam menulis cerita masih tergolong kurang. Hal ini tampak pada ketercapaian nilai menulis cerita siswa yang masih jauh dari kriteria Ketuntasan Minimal (KKM) yang telah ditetapkan oleh sekolah mengenai pembelajaran bahasa Indonesia khusunya menulis cerita yaitu sebesar 65. Dalam observasi awal tersebut diketahui hanya 10 siswa yang mencapai 
nilai tersebut pada saat survei awal. Pada siklus I dari 30 siswa, 10 siswa masih belum mencapai ketuntasan sesuai KKM, sedangkan siswa yang lain sudah mampu menulis cerita dengan baik. Pada siklus II hanya 5 siswa yang hadir dalam pertemuan tersebut yang belum mencapai nilai sesuai KKM atau sebesar $17 \%$.

Berikut disajikan grafik peningkatan persentase keberhasilan menulis cerita dengan metode gambar warna pada siswa kelas VI SDN 1 Sigli.

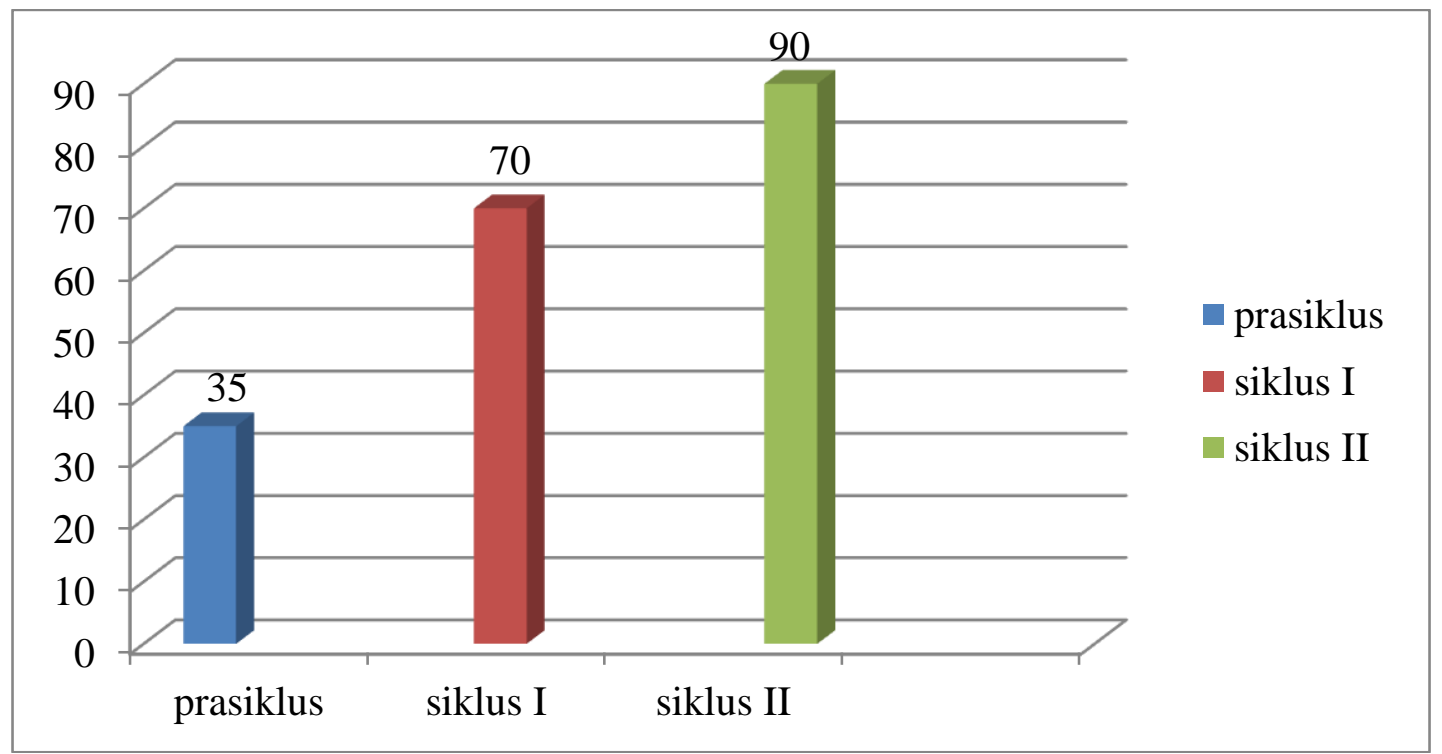

Grafik 2. Rekapitulasi Peningkatan Persentase Kemampuan Menulis Cerita Siswa Kelas VI SDN 1 Sigli

Berdasarkan grafik perolehan nilai keaktifan dan kemampuan menulis cerita di atas, maka dapat dilihat terdapat peningkatan dari sebelum tindakan hingga sesudah tindakan. Peningkatan kemampuan menulis cerita siswa tersebut dapat terjadi karena dilaksanakan pembelajaran menulis cerita dengan penggunaan media film animasi yang semakin baik dari siklus ke siklus. Dari hasil observasi dan refleksi tiap siklus dapat dijadikan pedoman untuk perbaikan pembelajaran berikutnya.

\section{SIMPULAN DAN SARAN}

Berdasarkan hasil penelitian tindakan kelas yang dilaksanakan dalam dua siklus, maka dapat ditarik simpulan bahwa pembelajaran dengan menggunakan media film animasi dapat meningkatkan: (1) Keaktifan siswa dalam pembelajaran menulis cerita di SDN 1 Sigli. Peningkatan keaktifan siswa dalam pembelajaran menulis cerita pada tiap siklus yaitu; sebelum tindakan nilai rata-rata keaktifan siswa 30 dengan kriteria kurang, pada siklus I nilai 
rata-rata 65 dengan kriteria cukup dan pada siklus II meningkat menjadi 85 dengan kriteria baik; dan (2) Kemampuan menulis cerita pada siswa kelas VI SDN 1 Sigli. Peningkatan kemampuan menulis cerita tersebut dapat dibuktikan dengan meningkatnya nilai kemampuan menulis cerita pada setiap siklus yaitu: sebelum tindakan nilai rata-rata kemampuan menulis cerita siswa 35, siklus I nilai rata-rata kemampuan menulis cerita siswa 70 dan siklus II nilai rata-rata kemampuan menulis cerita siswa 90.

Berdasarkan simpulan di atas, maka peneliti memberikan saran-saran sebagai berikut. Pertama, sebagai bahan masukan bagi sekolah dalam melaksanakan pembelajaran khususnya pembelajaran Bahasa Indonesia untuk meningkatkan kemampuan menulis cerita dengan menggunakan media film animasi. Kedua, guru hendaknya lebih kreatif dan inovatif dalam mengembangkan media, metode dan bahan ajar agar pembelajaran semakin menyenangkan. Ketiga, hendaknya siswa sering melakukan latihan menulis agar mudah dalam menuangkan gagasan lebih terampil dalam hal menulis.

\section{DAFTAR PUSTAKA}

Akhadiah, Sabarti, dkk. (1997). Pembinaan Keterampilan Menulis Bahasa Indonesia. Jakarta: Erlangga.

Arikunto, Suharsimi, dkk. (2012). Penelitian Tindakan Kelas. Jakarta: PT Bumi Askara.

Arsyad, Azhar. (2009). Media Pembelajaran. Jakarta: Rajawali Pers

Djuanda, D. (2006). Pembelajaran Bahasa Indonesia yang Komunikatif dan Menyenangkan. Jakarta: Depdiknas.

Hasan, M. Iqbal. (2002). Pokok-pokok Materi Metodologi Penelitian dan Aplikasinya. Bogor: Ghalia Indonesia.

Iskandarwassid dan Dadang Sunendar. (2008). Strategi Pembelajaran Bahasa. Bandung: PT. Remaja Rosdakarya.

Novi Resmini, dkk. (2006). Membaca dan Menulis di SD: Teori dan Pengajarannya. Bandung: UPI Press.

Soeparno. (2008). Media pembelajaran bahasa. Jakarta: PT. Intan Pariwara.

Sumardjo, Jakob. (2007). Catatan Kecil Tentang: Menulis Cerpen. Yogyakarta: Pustaka Pelajar.

Tarigan, Henry Guntur. (2008). Menulis: sebagai Suatu Keterampilan Berbahasa. Bandung: Angkasa. 